\title{
LC-MS as a Stability-Indicating Method for Analysis of Hyoscine N-Butyl Bromide under Stress Degradation Conditions with Identification of Degradation Products
}

\section{Nouruddin W Ali ${ }^{1}$, Mohammed Gamal ${ }^{1 *}$ and Mohammed Abdelkawy ${ }^{2}$}

${ }^{1}$ Pharmaceutical Analytical Chemistry Department, Faculty of Pharmacy, Beni-Suef University, Alshaheed shehata Ahmed, Hegazy St., 62574 Beni-Suef, Egypt ${ }^{2}$ Pharmaceutical Analytical Chemistry Department, Faculty of Pharmacy, Cairo University, Kasr El-Aini St., 11562, Cairo, Egypt

\begin{abstract}
Hyoscine N-Butyl Bromide (HBB) was subjected to different $\mathrm{ICH}$ prescribed stress conditions. It showed extensive decomposition under base hydrolytic conditions, while it was less liable to stress acid hydrolytic conditions. It showed also moderate degradation in response to oxidation stress of hydrogen peroxide. The drug showed no changes under photolysis conditions.

In total, a number of major degradation products were detected by HPLC and identified by LC-MS. For establishment of stability-indicating assay, the reaction solutions in which different degradation products were formed were prepared, and the separation was optimized by varying the HPLC conditions. An acceptable chromatograms was achieved using a C18 column using (water: methanol $50: 50 \mathrm{v} / \mathrm{v}, \mathrm{pH}$ adjusted to 3.9 with triflouroacetic acid) as a mobile phase with flow rate of $1.0 \mathrm{ml} \mathrm{min}{ }^{-1}$ and UV detection wavelength at $210 \mathrm{~nm}$. The percent of degradation was calculated in each run by measuring the intensity of the peak area of the intact drug at $6.2 \mathrm{~min}$. Complete degradation only occur in case of $5 \mathrm{~N} \mathrm{NaOH}$ indicates that the drug is very sensitive to alkaline hydrolysis.

The LC-MS study was carried out to identify the major degradation products using a sunfire (waters) C-18 column and a mobile phase comprising of acetonitrile: $0.1 \mathrm{M}$ ammonium acetate $(80: 20, \mathrm{v} / \mathrm{v})$ with flow rate of $1.0 \mathrm{ml}$ $\mathrm{min}^{-1}$. MS measurements were acquired in positive ion full scan modes from 50 to $400 \mathrm{amu}$. The $\mathrm{m} / \mathrm{z}$ values of the main peaks were investigated with the expected chemical structure of degradates.
\end{abstract}

Keywords: Hyoscine N-Butyl Bromide; Stress degradation; Stabilityindicating method; LC-MS; Degradation products

\section{Introduction}

Hyoscine N-Butyl Bromide is a quaternary ammonium anticholinergic agent. It has antispasmodic action on the smooth muscles of the gastrointestinal, biliary, and urinary tracts [1]. Its chemical name is (-)-( $1 S, 3 s, 5 R, 6 R, 7 S, 8 r)$-6,7-Epoxy-8-butyl-3$[(S)$-tropoyloxy]tropanium bromide [1] (Figure 1). HBB is a white, crystalline powder or colorless crystals, efflorescent, freely soluble in water, soluble in alcohol. It melts at about $139^{\circ} \mathrm{C}-141^{\circ} \mathrm{C}$ [2]. The empirical formula of $\mathrm{HBB}$ is $\mathrm{C}_{21} \mathrm{H}_{30} \mathrm{Br} \mathrm{N} \mathrm{O}_{4}$ and its molecular weight is 440.4 and 360.1 without Bromide atom.

Many analytical techniques have been reported in the literature for determination of $\mathrm{HBB}$ in pharmaceutical preparations using spectrophotometric methods [3-5], chromatographic methods [6-8], electrochemical methods [8-11], Capillary electrophoresis methods $[12,13]$ and titrimetric method [14]

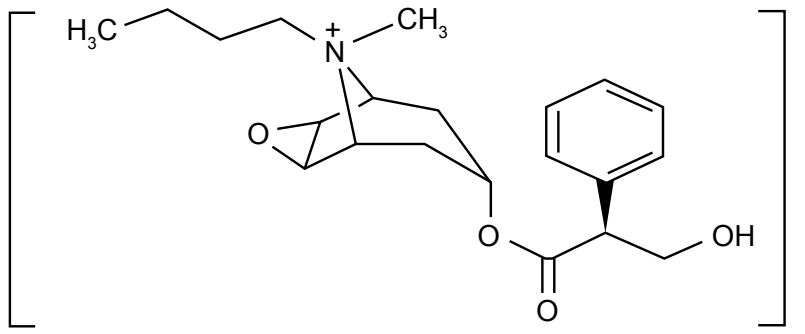

$\mathrm{Br}^{-}$

Figure 1: Structure of Hyoscine N-Butyl Bromide.
LC is a common technique. LC may be coupled with UV detection or mass spectrophotometry. Mass spectrophotometer is the most powerful analytical technique. LC-MS is a hyphenated technique; combing separation power of HPLC, with the great detection power of mass spectrometry. LC-MS provides online molecular masses identification without need of prior isolation.

LC-MS has many applications. It can be used for detection of low concentration of drug or poison, impurities profile, metabolite studies, bioequivalent and bioavailability studies.

Recently, LC-MS has been used for identification of degradation products for many drugs in stress conditions as Prulifloxacin [15], lornoxicam [16] Isoniazid [17] and Eletriptan hydro bromide [18].

Pharmaceutical drugs must be tested with a stability-indicating method before release to market according to good manufacturing practices.

So far to our present knowledge neither LC-MS nor HPLC

*Corresponding author: Mohammed Gamal, Pharmaceutical Analytica Chemistry Department, Faculty of Pharmacy, Beni-Suef University, Alshaheed shehata Ahmed, Hegazy St., 62574 Beni-Suef, Egypt, Tel: 002 01141618950; E-mail: mgamalm3000@yahoo.com

Received January 28, 2013; Accepted June 24, 2013; Published June 28, 2013

Citation: Ali NW, Gamal M, Abdelkawy M (2013) LC-MS as a Stability-Indicating Method for Analysis of Hyoscine N-Butyl Bromide under Stress Degradation Conditions with Identification of Degradation Products. Pharm Anal Acta S7: 006. doi:10.4172/2153-2435.S7-006

Copyright: (C) 2013 Ali NW, et al. This is an open-access article distributed unde the terms of the Creative Commons Attribution License, which permits unrestricted use, distribution, and reproduction in any medium, provided the original author and source are credited. 
Citation: Ali NW, Gamal M, Abdelkawy M (2013) LC-MS as a Stability-Indicating Method for Analysis of Hyoscine N-Butyl Bromide under Stress Degradation Conditions with Identification of Degradation Products. Pharm Anal Acta S7: 006. doi:10.4172/2153-2435.S7-006

Page 2 of 5

stability-indicating analytical method for HBB has been published in the literature, although a UPLC/MS-MS method for determination of the drug in plasma has been published [8]. However this method does not discuss the identity of the degradation products and does not offer a stability study. The present work is dealing with HPLC as stability indicating method, developing forced degradation studies according to ICH guidelines and discussing probability of formed degradates with LC-MS (Table 1).

\section{Experimental}

\section{Samples}

Hyoscine N-Butyl Bromide (HBB) was kindly supplied by CID Co. Chemical Industries Development, Giza, Egypt. Its purity was found to be $99.21 \pm 0.602$ according to the company analysis certificate (HPLC).

\section{Chemical and reagents}

All chemicals and solvents were of analytical grade and were used without further purification.

- Hydrochloric acid, Orthophosphoric acid, glacial acetic acid,
Sodium hydroxide, hydrogen peroxide and ammonium acetate all are from (El - Nasr Pharmaceutical Chemicals Co, AbuZabaal, Cairo, Egypt).

- Acetonitrile (E.Merck, Germany).Methanol HPLC grade (Sigma Aldrich, Germany).

- Deionised water (SEDICO pharmaceutical Co., $6^{\text {th }}$ October City, Egypt).

Trifluoroacetic acid from Spectrochem, India.

\section{Instrumentations}

- Shimadzu Class - LC 10 AD Liquid Chromatography supplied with Shimadzu SPD - 10 A UV - VIS Detector (Shimadzu Corporation, Japan). Phenomenex C18 $(25 \mathrm{~cm} \times 4.6 \mathrm{~mm}$ i.d, $5 \mu \mathrm{m}$ particle size) column was used as a stationary phase for HPLC determinations (USA).

- The LC system is integrated system shimadzu controller (CBM20Alite). The system consist of pump (Shimadzu LC20AD), auto injector (Shimadzu SIL20A), the device is

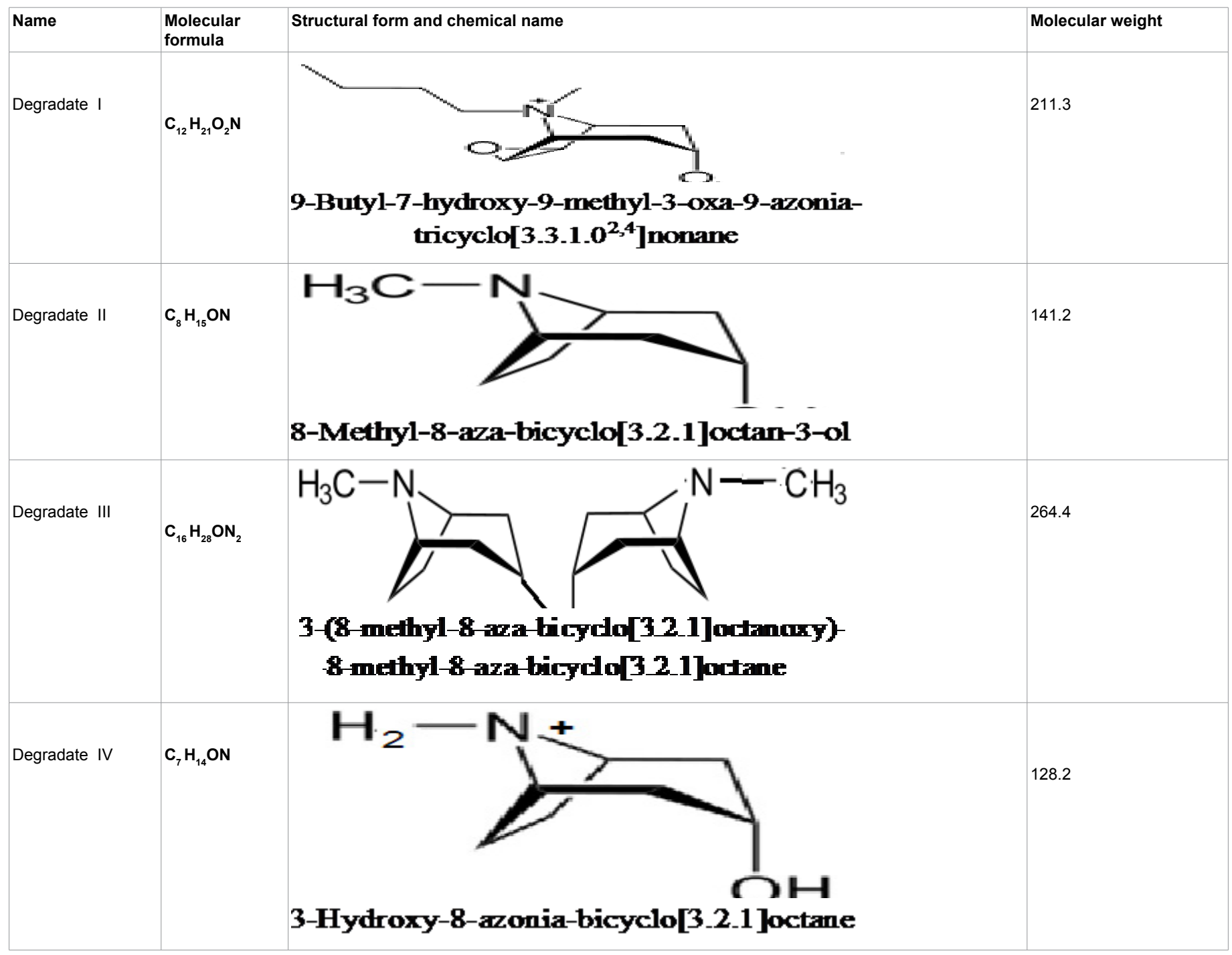

Table 1: Expected Chemical structures of the scanned compounds and their masses values. 
Citation: Ali NW, Gamal M, Abdelkawy M (2013) LC-MS as a Stability-Indicating Method for Analysis of Hyoscine N-Butyl Bromide under Stress Degradation Conditions with Identification of Degradation Products. Pharm Anal Acta S7: 006. doi:10.4172/2153-2435.S7-006

Page 3 of 5

Triple Quadrupole LC/MS/MS Mass Spectrometer (API 3200). The chromatographic separations were carried out on a sunfire from waters C-18 $(50 \mathrm{~mm} \times 4.6 \mathrm{~mm}$ i.d., particle size $5 \mu \mathrm{m})$ column.

- Sonix TV ss-series ultrasonicator (USA).

\section{Preparation of samples for HPLC and LC-MS analyses}

A sample concentration of $1000 \mu \mathrm{g} \mathrm{ml}^{-1}$ was used to conduct degradation studies. The degradation samples were injected directly without neutralization (in case of acid and base hydrolysis) and diluted suitably to a concentration of $2.5 \mu \mathrm{g} \mathrm{ml}^{-1}$ for analysis by LC-MS while degradation samples for HPLC were injected directly without any dilution. All the solutions were filtered using 0.22 micron membrane filter before HPLC and LC-MS injections.

\section{Forced degradation studies}

Stress studies were carried out under ICH prescribed stress conditions [19]. follow

Forced degradation was carried out under stress conditions as

$\checkmark$ For photolysis conditions (direct sunlight for 12 hours).

$\checkmark$ For acidic conditions (0.1 N hydrochloric acid with reflux for 12 hours) and ( $5 \mathrm{~N}$ hydrochloric acid with reflux for 3 hours).

$\checkmark$ For basic conditions ( $0.1 \mathrm{~N}$ sodium hydroxide with reflux for 12 hours) and ( $5 \mathrm{~N}$ sodium hydroxide with reflux for 3 hours).

$\checkmark$ For oxidative conditions (3.0 \% $\mathrm{H}_{2} \mathrm{O}_{2}$ for 12 hours) and (30.0\% $\mathrm{H}_{2} \mathrm{O}_{2}$ for 12 hours).

Degradation studies in acidic and basic media were carried out at $80^{\circ} \mathrm{C}$. After the different treatments were completed, all the solutions and blanks (solutions without any treatment) were filtered with a 0.45 $\mu \mathrm{m}$ syringe filtration disk to the vials for injection in HPLC and LC-MS systems. The purpose of the LC-MS method is to scan masses of HBB and its degradation products (Table 2).

\section{Linearity and construction of calibration curve for $\mathrm{HBB}$ by HPLC method}

Accurate aliquots equivalent to (20-500) $\mu \mathrm{g}$ of $\mathrm{HBB}$ were transferred from its corresponding working solutions $\left(100 \mu \mathrm{g} \cdot \mathrm{mL}^{-1}\right)$ into a set of a series of $10-\mathrm{mL}$ volumetric flasks. The volume was completed with methanol. Triplicate $20 \mu \mathrm{L}$ injections were made for each concentration. The separation was done on $\mathrm{C}_{18}$ column using (water: methanol 50: 50 $\mathrm{v} / \mathrm{v}, \mathrm{pH}$ adjusted to 3.9 with triflouroacetic acid) as a mobile phase. All solvents were filtered through a $0.45 \mu \mathrm{m}$ membrane filters before use and degassed in an ultrasonic bath for $20 \mathrm{~min}$. Record the chromatograms at ambient temperature maintaining the flow rate at $1.0 \mathrm{~mL} \cdot \mathrm{min}^{-1}$ and detect the effluent at $210 \mathrm{~nm}$. Construct the calibration curves for HBB by plotting the peak area/ $10^{4}$ versus the corresponding concentration and then compute the regression equation.

\section{LC-MS conditions and Characterization of degradation $\operatorname{product}(s)$}

First, the reaction solutions were individually subjected to LCMS. The studies were conducted using a mobile phase composed of (acetonitrile: $0.1 \mathrm{M}$ ammonium acetate $80: 20, \mathrm{~V} / \mathrm{V}$ ) with a flow rate of $1 \mathrm{~mL} \cdot \mathrm{min}^{-1}$ with isocratic flow. LC-MS studies were carried out in Turbo spray ionization (TSI), scan type is Q1 Multiple Ions (Q1 MI). MS measurements were acquired in positive ion full scan modes from 50 to $400 \mathrm{amu}$. The LC-MS method can be used for characterization of both the degradation products and the intact drug. LC-MS studies were performed to determine $\mathrm{m} / z$ values of the major degradation products formed under various stress test conditions. The obtained values were compared with the molecular weights of expected degradation products of $\mathrm{HBB}$.

\section{Results and Discussion}

Simple, selective, sensitive and accurate isocratic HPLC method was adopted for the determination of HBB in presence of degradation products without prior separation. Mass spectrum scanning by LC-MS was developed for determination of degradation behavior of HBB and Characterization of degradation product(s).

A satisfactory separation in HPLC method was obtained by using C18 $(25 \mathrm{~cm} \times 4.6 \mathrm{~mm}$ i.d. $5 \mu \mathrm{m}$ particle size $)$ column as a stationary phase and using (water: methanol 50:50, v/v pH adjusted to 3.9 with $\mathrm{CF}_{3} \mathrm{COOH}$ acid) as a mobile phase, maintaining the flow rate at $1.0 \mathrm{~mL}$ $\mathrm{min}^{-1}$ with UV detection at $210 \mathrm{~nm}$. The retention time for HBB was 6.2 min, Figure 2 (Data included as supplementary).

\section{HPLC method validation} [19].

Method validation was performed according to ICH guidelines

Linearity of the proposed method was evaluated and it was evident in the concentration range of $2-50 \mu \mathrm{g} \cdot \mathrm{mL}^{-1}$ for HBB. Good linearity was evident by the high value of the correlation coefficient and the low intercept value, (Figure 3 ) and (Table 3 ). The regression equations were calculated and found to be:

$$
\mathrm{Y}=2.507 \mathrm{C}-0.409 \mathrm{r}=0.9997
$$

Where $\mathrm{Y}$ is the peak area $/ 10^{4}, \mathrm{C}$ is $\mathrm{HBB}$ concentration in $\mu \mathrm{g} \cdot \mathrm{mL}^{-1}$ and $\mathrm{r}$ is the correlation coefficient.

Precision of the proposed HPLC method was evident as shown in Table 3.

\begin{tabular}{|c|c|c|c|}
\hline Degradation Studies & Time & Assay of HBB $\%$ of peak area & Remarks \\
\hline $\begin{array}{l}\text { 1-Blank } \\
\text { 2- Photolytic Condition } \\
\text { 3-Base hydrolysis }\left(0.1 \mathrm{~N} \mathrm{NaOH} \text { at } 80^{\circ} \mathrm{C}\right) \\
\text { 4- Base hydrolysis }\left(5 \mathrm{~N} \mathrm{NaOH} \text { at } 80^{\circ} \mathrm{C}\right) \\
\text { 5-Acid hydrolysis }\left(0.1 \mathrm{~N} \mathrm{HCl} \text { at } 80^{\circ} \mathrm{C}\right) \\
\text { 6- Acid hydrolysis }\left(5 \mathrm{~N} \mathrm{HCl} \text { at } 80^{\circ} \mathrm{C}\right) \\
\text { 7-Oxidation by } 3 \% \mathrm{H}_{2} \mathrm{O}_{2} \text { at } 25^{\circ} \mathrm{C} \\
\text { 8- Oxidation by } 30 \% \mathrm{H}_{2} \mathrm{O}_{2} \text { at } 25^{\circ} \mathrm{C}\end{array}$ & $\begin{array}{l}12 \mathrm{~h} \\
12 \mathrm{~h} \\
3 \mathrm{~h} \\
12 \mathrm{~h} \\
3 \mathrm{~h} \\
12 \mathrm{~h} \\
3 \mathrm{~h}\end{array}$ & $\begin{array}{l}99.00 \\
99.02 \\
25.00 \\
0.00 \\
99.00 \\
65.00 \\
90.00 \\
72.00\end{array}$ & $\begin{array}{l}\text { No significant } \\
\text { degradation observed } \\
\text { Degradation products I and II observed } \\
\text { Degradation products I, II and III observed. } \\
\text { No significant } \\
\text { degradation observed } \\
\text { Degradation product II } \\
\text { observed } \\
\text { unidentified Degradation products observed } \\
\text { Degradation product IV } \\
\text { Observed }\end{array}$ \\
\hline
\end{tabular}

Table 2: Mass balance for HBB drug substance in presence of degradation products formed during forced degradation studies. 
Citation: Ali NW, Gamal M, Abdelkawy M (2013) LC-MS as a Stability-Indicating Method for Analysis of Hyoscine N-Butyl Bromide under Stress Degradation Conditions with Identification of Degradation Products. Pharm Anal Acta S7: 006. doi:10.4172/2153-2435.S7-006

Page 4 of 5

Accuracy of the proposed method was checked by applying the proposed method for determination of different samples of standard HBB. The concentrations were calculated from the corresponding regression equation. The results obtained as shown in Table 4.

Specificity of the proposed method is evident HPLC chromatograms in Figure 2.

System suitability tests are based on the concept that the equipment, electronics, analytical operations and samples constitute an integral system that can be evaluated as whole. System suitability is used to ensure system performance before or during the analysis of the drugs. System suitability was checked by calculating the capacity factor (K'), tailing factor(T), column efficiency $(\mathrm{N})$ and resolution(Rs), where the system was found to be suitable as shown in Table 5 .

\section{Degradation behavior and Characterization of degradation product(s) according to HPLC chromatograms}

HPLC chromatograms at $210 \mathrm{~nm}$ for all samples of standard drug, acid degradation, base degradation, oxidative degradation and photolysis are shown in Figure 3. The percent of intact HBB was calculated according to peak area of HPLC chromatograms as shown in Table 2.

Base Hydrolysis: Appearance of new peaks in base hydrolysis with $0.1 \mathrm{~N} \mathrm{NaOH}$ at $\mathrm{R}_{\mathrm{t}}=2.9,5.4 \mathrm{~min}$ and reduction of peak area of $\mathrm{HBB}$ $\left(\mathrm{R}_{\mathrm{t}}=6.2 \mathrm{~min}\right)$ indicate significant degradation of the drug in slightly basic medium (about $75 \%$ degradation).

Similarly, Appearance of new broad peak in base hydrolysis with $5 \mathrm{~N} \mathrm{NaOH}$ at $\mathrm{R}_{\mathrm{t}}=3.4$ min and complete disappearance of HBB peak $\left(\mathrm{R}_{\mathrm{t}}=6.2 \mathrm{~min}\right)$ indicate complete degradation of the drug in highly basic medium.

The retention times of degradates in $0.1 \mathrm{~N} \mathrm{NaOH}$ differ from those of $5 \mathrm{~N} \mathrm{NaOH}$, this indicates that degradation products differ according to strength of the used base. This result matches with different mass spectra obtained for degradation in $0.1 \mathrm{~N} \mathrm{NaOH}$ and $5 \mathrm{~N} \mathrm{NaOH}$.

Low concentration of the base $(0.1 \mathrm{~N} \mathrm{NaOH})$ is not enough for complete degradation of the drug even in longer time of reflux (about 12 hours).

Acid hydrolysis: No HPLC chromatogram changes appear in 0.1 $\mathrm{N} \mathrm{HCl}$ chromatogram; this indicates that no significant degradation occurs in slightly acidic medium.

\section{HYOSCINE BUTYL BROMIDE}

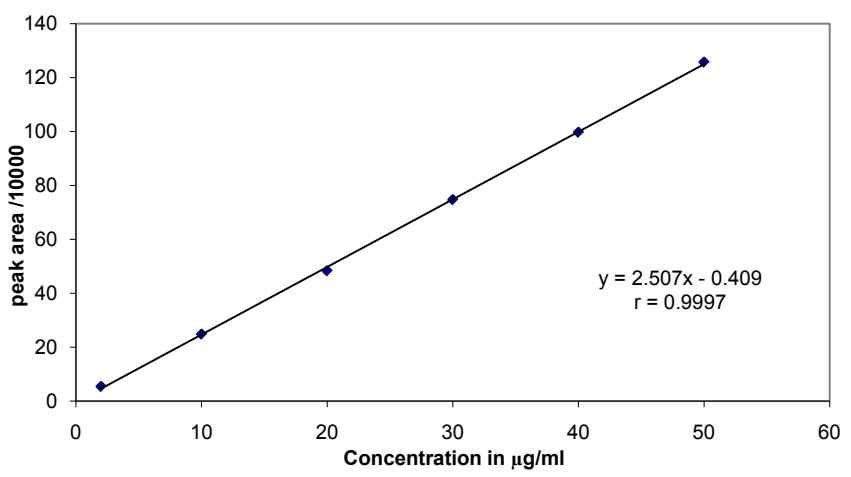

Figure 3: Linearity of the peak area at $210 \mathrm{~nm}$ to the corresponding concentration of HBB $\left(2-50 \mu \mathrm{g} \mathrm{mL}^{-1}\right)$ using HPLC method.

\begin{tabular}{|l|l|}
\hline Parameters & HBB \\
\hline Range $\left(\mu \mathrm{g} \cdot \mathrm{mL}^{-1}\right)$ & $2-50\left(\mu \mathrm{g} \cdot \mathrm{mL}^{-1)}\right.$ \\
\hline Slope & 2.507 \\
\hline Intercept & -0.409 \\
\hline Correlation coefficient $(\mathrm{r})$ & 0.9997 \\
\hline $\begin{array}{l}\text { Accuracy } \\
(\text { mean } \pm \text { SD) }\end{array}$ & $100.20 \pm 0.806$ \\
\hline$(\text { RSD } \%)^{\mathrm{a} *}$ & 0.693 \\
\hline$(\text { RSD } \%)^{\mathrm{b} *}$ & 0.716 \\
\hline
\end{tabular}

$(\mathrm{RSD} \%)^{\mathrm{a} *},(\mathrm{RSD} \%)^{\mathrm{b} *}$ the intra-day and inter-day relative standard deviations of the average of concentrations $\left(20,40\right.$ and $50 \mu \mathrm{g} \cdot \mathrm{mL}^{-1}$ for each )

Table 3: Results of assay validation parameters of HPLC for the determination of HBB.

\begin{tabular}{|c|c|c|}
\hline Taken $\left(\boldsymbol{\mu g} \mathbf{~ m L}^{-1}\right)$ & Found $\left(\boldsymbol{\mu g} \mathbf{~ m L}^{-1}\right)$ & Recovery $\%$ \\
\hline 2.00 & 2.03 & 101.50 \\
10.00 & 10.09 & 100.90 \\
20.00 & 19.95 & 99.75 \\
30.00 & 29.92 & 99.73 \\
40.00 & 39.80 & 99.50 \\
50.00 & 49.90 & 99.80 \\
\hline \multicolumn{2}{|c|}{ Mean \pm SD } & $100.20 \pm 0.806$ \\
\hline
\end{tabular}

*Average of three determinations

Table 4: Results of accuracy for determination of pure authentic of HBB by the proposed HPLC method.

\begin{tabular}{|l|l|l|}
\hline Parameters & $\begin{array}{l}\text { Obtained value } \\
\text { for HBB }\end{array}$ & Reference value \\
\hline Resolution $\left(\mathrm{R}_{\mathrm{s}}\right)$ & 4.11 & $>1.5$ \\
\hline Capacity factor(K') & 1.48 & $1-10$ acceptable \\
\hline Tailing factor $(\mathrm{T})$ & 1.20 & $<1.5-2$ \\
\hline $\begin{array}{l}\text { Number of Theoretical } \\
\text { plate(N) }\end{array}$ & 5082975 & Increases with increases efficiency \\
\hline $\begin{array}{l}\text { HETP }(\mathrm{cm} \text {.plate } \\
\text { Height equivalent to } \\
\text { theoretical plate }\end{array}$ & 0.4918 & $\begin{array}{l}\text { The smaller the value, the higher the } \\
\text { efficiency }\end{array}$ \\
\hline
\end{tabular}

Table 5: Statistical analysis of parameters required for system suitability testing of HPLC method.

Decrease of peak area of $\mathrm{HBB}$ at $\mathrm{R}_{\mathrm{t}}=6.2 \mathrm{~min}$ in chromatogram of $5 \mathrm{~N}$ $\mathrm{HCl}$ than that of chromatogram of $0.1 \mathrm{~N} \mathrm{HCl}$ and appearance of new peaks in acid hydrolysis with $5 \mathrm{~N} \mathrm{HCl}$ at $\mathrm{R}_{\mathrm{t}}=3.3,9.8,10.3$ min indicate that percent of degradation in acidic medium is greatly increased by increasing the concentration of the acid (about 35\% degradation).

Oxidation by $\mathrm{H}_{2} \mathrm{O}_{2}$ : Decrease of peak area of $\mathrm{HBB}$ in chromatogram of $30 \% \mathrm{H}_{2} \mathrm{O}_{2}$ than that of chromatogram of $3 \% \mathrm{H}_{2} \mathrm{O}_{2}$ indicates that percent of degradation is greatly increased by increasing the strength of used $\mathrm{H}_{2} \mathrm{O}_{2}$.

About $10 \%$ degradation was observed in oxidation by $3 \%$ hydrogen peroxide with formation of new peak at 13.3 min while $28 \%$ decomposition occurred in oxidation by $30 \%$ hydrogen peroxide with formation of new peaks at 9.3 and $10.3 \mathrm{~min}$.

Photolysis: Evidently, the complete similarity between chromatograms of standard and photolysis sample indicates that light has no effect on HBB stability.

Degradation behavior and characterization of degradation product(s) according to mass spectrum scanning

In total, four major degradation products were detected by MS measurements on decomposition of the drug under various stress conditions (Table 1). The degradation behavior of the drug in individual stress conditions is discussed below according to mass 
Citation: Ali NW, Gamal M, Abdelkawy M (2013) LC-MS as a Stability-Indicating Method for Analysis of Hyoscine N-Butyl Bromide under Stress Degradation Conditions with Identification of Degradation Products. Pharm Anal Acta S7: 006. doi:10.4172/2153-2435.S7-006

Page 5 of 5

spectrum scanning, (Figure 4 data included as supplementary). Types of formed degradates in each stress degradation condition discussed collectively in Table 2 .

Base hydrolysis: The drug degraded to great extent within 12 hours on heating at $80^{\circ} \mathrm{C}$ in $0.1 \mathrm{~N} \mathrm{NaOH}$, forming mainly degradate I $(212 \mathrm{~m} / \mathrm{z})$ and to less extent degradate II $(142 \mathrm{~m} / \mathrm{z})$. This indicates the cleavage of ester bond between tropic acid and $\mathrm{N}$ butyle oxy tropine base.

The drug degraded completely upon hydrolysis of $\mathrm{HBB}$ after reflux with $5 \mathrm{~N} \mathrm{NaOH}$ for 3 hours at $80^{\circ} \mathrm{C}$ but forming different degradetes mainly degradate I $(212 \mathrm{~m} / \mathrm{z})$ and to moderate extent degradate III (268 $\mathrm{m} / \mathrm{z}$ ). This indicates the cleavage of ester bond between tropic acid and $\mathrm{N}$ butyle oxy tropine base and also formation of dimer of tropine base through formation of ether bond.

Acid Hydrolysis: The drug was stable with 12 hours on heating at $80^{\circ} \mathrm{C}$ in $0.1 \mathrm{~N} \mathrm{HCl}$. This indicates that $\mathrm{HBB}$ resist acid hydrolysis and remain stable in the acidic juice of stomach so the drug is valid for oral route of administration.

Different results obtained upon reflux with $5 \mathrm{~N} \mathrm{HCl}$ for 3 hours at $80^{\circ} \mathrm{C}$ as the drug degradated by $35 \%$ to form mainly degradate II $(142 \mathrm{~m} / \mathrm{z})$. This indicates the cleavage of ester bond and formation of tropine base.

Oxidation by $\mathrm{H}_{2} \mathrm{O}_{2}$ : The drug was relatively stable to $3 \%$ hydrogen peroxide at room temperature for 12 hours and about $10 \%$ degradation was observed with formation of two unidentified new degradate of ( 206.2 and $153.3 \mathrm{~m} / \mathrm{z}$ ). However, $28 \%$ decomposition occurred in $30 \%$ hydrogen peroxide, resulting in formation of mainly degradate IV of $(130.4 \mathrm{~m} / \mathrm{z})$

Photolysis: The LC profiles of light exposed drug samples in methyl alcohol were similar to that in the dark, indicating that light had no particular influence on the drug in solution.

\section{Conclusions}

It was possible in this study to develop a stability-indicating LC-MS method for $\mathrm{HBB}$ with identification of degradation products of $\mathrm{HBB}$ by subjecting the drug to ICH recommended stress conditions. The drug got well separated from degradation products by HPLC and the degradates were identified from each other in mass spectra of LC-MS.

The method is proved to be simple, specific, stability indicating and valid for the routine analysis of HBB in bulk drug form or in pharmaceutical formulations.

\section{Acknowledgment}

The authors wish to thank Dr. Ahmed Hassan the manager of LC-MS unit in genuine research center (GRC) for his co-operation in carrying out this work.

\section{References}

1. Martindale (2007) The complete drug reference "The Extra Pharmacopoeia (31stedn), Pharmaceutical press London.

2. The Merck Index (2001) MercK Research Laboratories Division of Merck and Co. INC. (13thedn), White house station, NJ.
3. Mahrous M, Daabees $H$, Beltagy $Y$ (1992) New sensitive method for the analysis of some non uv absorbing quaternised compounds. Spectroscopy letters $25: 389-400$

4. Issopoulos P, Pavlou-Zervou E (1994) Application of ion pair complexes of some acid-base indicators in pharmaceutical analysis. I: Spectrophotometric microdetermination of L-hyoscine butyl bromide by its ion pair complex with methyl organge. II Farmaco 49: 205-210.

5. Thomos KM, Dabholkar DA, Jain CL (1994) Spectrophotometric determination of hyoscine butyl bromide in pharmaceutical formulations. Indian Drugs 31 391-392.

6. Papadoyannis I, Zotou A, Samanidou V, Georgarakis M (1994) Solid-phase extraction and RP-HPLC analysis of atropine sulphate and scopolamine$\mathrm{N}$-butylbromide in pharmaceutical preparations and biological fluids. Instrumentation science \& technology $22: 83-103$.

7. Lau O W, Mok C S (1997) High-performance liquid chromatographic determination of atropine and atropine-like alkaloids in pharmaceutical preparations with indirect conductometric detection. Journal of Chromatography A $766: 270-276$

8. Favreto WAJ, Pugens Pinto AM, Manfio JL, Fiametti KG, Percio MF, et al. (2012) Development and validation of a UPLC-ESI-MS/MS method for the determination of $\mathrm{N}$-butylscopolamine in human plasma: Application to a bioequivalence study. Drug Test Anal 4 : 215-221.

9. El-Saharty YS, Metwaly FH, Refaat M, El-Khateeb SZ (2007) Development of membrane electrodes for the selective determination of hyoscine butylbromide. Talanta 72: 675-681.

10. Ganjali MR, Memari Z, Larijani B, Faridbod F, Riahi S, et al. (2010) Symmetric and Asymmetric Hyoscine Membrane Sensor for Determination of Hyoscine Butyl Bromide in Pharmaceutical Formulation and Biological Fluids; A Computational Study. Sensor Letters 8 : 545-553.

11. Wassel A A, Abu-Talib N (2010) Sensors membrane electrodes for sensitive determination of hyoscine butylbromide in pharmaceutical formulation and in human plasma. Journal of Sensing in electroanalysis 5 .

12. Cherkaoui S, Mateus L, Christen P, Veuthey JL (1999) Nonaqueous versus aqueous capillary electrophoresis for the dosage of $\mathrm{N}$-butylscopolamine in various pharmaceutical formulations. J Pharm Biomed Anal 21: 165-174.

13. Chang YS, Ku YR, Wen KC, Ho LK (2000) Analysis of synthetic gastrointestinal drugs in adulterated traditional chinese medicines by HPCE. Journal of Liquid Chromatography \& Related Technologies 23: 2009-2019.

14. The British Pharmacopoeia (2009) British Pharmacopoeia Commission London.

15. Raju B, Ramesh M, Srinivas R, Raju SS, Venkateswarlu Y (2011) Identification and characterization of stressed degradation products of prulifloxacin using LC-ESI-MS/Q-TOF, MSn experiments: Development of a validated specific stability-indicating LC-MS method. J Pharma Biomed Anal 56: 560-568.

16. Modhave DT, Handa T, Shah RP, Singh S (2011) Stress degradation studies on lornoxicam using LC, LC-MS/TOF and LC-MSn. J Pharm Biomed Anal 56 538-545.

17. Bhutani $H$, Singh S, Vir S, Bhutani KK, Kumar R, et al (2007) LC and LC MS study of stress decomposition behaviour of isoniazid and establishment of validated stability-indicating assay method. J Pharm Biomed Anal 43: 1213 1220.

18. JociÄ $\ddagger$ B, ZeceviÄ $\ddagger$ M, ZivanoviÄ $\ddagger$, ProtiÄ $\ddagger A$, Jadranin M, et al. (2009) Study of forced degradation behavior of eletriptan hydrobromide by LC and LC-MS and development of stability-indicating method. J Pharm Biomed Anal 50: 622 629

19. ICH (2003) Stability Testing of New Drug Substances and Products. International Conference on Harmonization, IFPMA, Geneva. 